\title{
A New Method for Evaluating Author's Scientific Impact by using an Eigenfactor Derived Scoring System
}

\author{
Sorin Hostiuc ${ }^{1 *}$ and lonuț $\mathrm{Negoi}^{2}$ \\ ${ }^{1}$ (a) Carol Davila University of Medicine and Pharmacy, Bucharest, Romania (b) National Institute of Legal Medicine Bucharest, Dept. of \\ Forensic Pathology, ROMANIA. \\ ${ }^{2}$ Carol Davila University of Medicine and Pharmacy, Bucharest, ROMANIA.
}

\begin{abstract}
Purpose: This paper aims to propose a new method of quantifying the scientific impact based on the Eigenfactor. Materials and Methods: We propose four scores, all based on a common parameter, called $E_{m p}$ : (1) article median score $\left(A E_{m p}\right)$ computed by summing the $E_{m p} s$ for all articles published by a researcher, (2) $A E_{m p}$ Main, which only includes the articles published as a main author by a specific researcher, (3) article weighted median score $\left(\mathrm{BE}_{\mathrm{mp}}\right)$, which is obtained by summing the $E_{m p}$ values of the journals in which the author has published, divided by the number of authors, and (4) citation weighted median score $\left(C E_{m p}\right)$, calculated by summing the $E_{m p}$ values of the journals in which the articles of the researcher were cited. We give $t$ two calculation examples, for the Medicine, Legal, and Anatomy \& Morphology ISI categories.
\end{abstract}

Key words: Citation pattern, Prestige, Eigenfactor, Alternatives to $\mathrm{h}$ index.

\section{INTRODUCTION}

The scientific impact of a researcher may be determined through various methods such as peer review, number of grants won, number of articles published, or various scientometric indicators. ${ }^{[1]}$ Commonly used scientometric indicators are the impact factor (IF) of the journals where the author has published scientific articles, the number of articles, of citations or the h-index.

The number of citations is useful for analyzing the impact of a scientist by quantifying his/hers visibility within the scientific community; nevertheless, it has a relatively low level of discrimination, ${ }^{[1]}$ as it is highly dependent on the

*Address for correspondence:

Sos.Vitan Barzesti 9, 042122, Sector 4 Bucuresti, ROMANIA.

Phone no: 0040723791072

E-mail: soraer@gmail.com, sorin.hostiuc@legmed.ro.

\begin{tabular}{|c|c|}
\hline \multicolumn{2}{|c|}{ Access this article online } \\
\hline Official Publication of & \\
\hline & $\begin{array}{l}\text { Website: } \\
\text { www.jscires.org }\end{array}$ \\
\hline 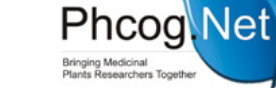 & $\begin{array}{l}\text { DOI: } \\
\text { 10.5530/jscires.5.1.11 }\end{array}$ \\
\hline
\end{tabular}

field of study. Some disciplines, such as medical genetics or chemistry, are likely to be cited more often than, for instance, medical informatics. Moreover, the number of citations does not say anything about the number of articles that generated them, allowing manipulation through selfand cross-citations.

The h-index, developed by Hirsch, ${ }^{[2]}$ assigns a value $\mathrm{h}$ if an author has $h$ articles cited at least $h$ times. For example, assuming that an author has 5 articles, cited 20,3, 3, 1 and 0 times respectively, the h-index would be 3 , as this author would have three articles cited at least three times. The h-index is currently the most widely used performance indicator. However, it has a series of disadvantages and inconsistencies like: it is counterintuitive, doesn't take into account the way the citations were obtained, doesn't take into account the number of authors, and so on. For more details on the subject see the critics of h-index brought by Glanzel et al and others. ${ }^{[3-5]}$ These disadvantages motivated scientometrics' researchers to look for alternatives to the h-index. This led to the creation of other indexes, such as the $\mathrm{m}$ index,${ }^{[6,7]} \mathrm{g}$ index,${ }^{[8]} \mathrm{e}$ index, ${ }^{[0]} \mathrm{h}^{2}$ indexes. ${ }^{[10]}$ Previous studies have already reported detailed comparisons of these indexes. ${ }^{[1]}$

Another very useful set of indicators are the Eigenfactor (EF) and the Article Influence Score (AIS). EF, developed 
Hostiuc and Negoi.: Evaluating the scientific impact for authors

Table 1: $\mathrm{E}_{\mathrm{mp}}$ in the area of Medicine, Legal. EF=Eigenfactor, AIS=Article Influence Score

\begin{tabular}{|c|c|c|c|c|c|c|}
\hline TITLE & IF & EF & AIS & No Art & Ep & $\mathbf{E}_{\mathrm{mp}}$ \\
\hline $\begin{array}{l}\text { J LAW MED } \\
\text { ETHICS }\end{array}$ & 1.215 & 0.00518 & 0.726 & 388 & 1.33505E-05 & 1.3617527 \\
\hline $\begin{array}{l}\text { FORENSIC SCI } \\
\text { INT-GEN }\end{array}$ & 3.082 & 0.00341 & 0.695 & 267 & 1.27715E-05 & 1.3026968 \\
\hline $\begin{array}{c}\text { J FORENSIC LEG } \\
\text { MED }\end{array}$ & 1.098 & 0.00150 & & 133 & 1.12782E-05 & 1.1503761 \\
\hline INT J LEGAL MED & 2.587 & 0.00453 & 0.610 & 404 & 1.12129E-05 & 1.1437130 \\
\hline $\begin{array}{c}\text { FORENSIC SCI } \\
\text { INT }\end{array}$ & 2.301 & 0.01633 & 0.610 & 1457 & 1.1208E-05 & 1.1432122 \\
\hline $\begin{array}{l}\text { EXPERT OPIN } \\
\text { THER PAT }\end{array}$ & 3.571 & 0.00541 & 0.609 & 484 & 1.11777E-05 & 1.1401241 \\
\hline $\begin{array}{c}\text { REGUL TOXICOL } \\
\text { PHARM }\end{array}$ & 2.427 & 0.00595 & 0.568 & 571 & 1.04203E-05 & 1.0628723 \\
\hline $\begin{array}{l}\text { FORENSIC SCI } \\
\text { MED PAT }\end{array}$ & 1.444 & 0.00100 & - & 102 & $\left(E_{m}\right) 9.80392 E-06$ & 1.000000 \\
\hline J FORENSIC SCI & 1.229 & 0.00965 & 0.440 & 1193 & 8.08885E-06 & 0.8250629 \\
\hline SCI JUSTICE & 1.597 & 0.00094 & 0.429 & 119 & 7.89916E-06 & 0.8057144 \\
\hline $\begin{array}{l}\text { AM J FOREN } \\
\text { MED PATH }\end{array}$ & 0.883 & 0.00203 & 0.263 & 420 & 4.83333E-06 & 0.4930000 \\
\hline $\begin{array}{c}\text { AUST J } \\
\text { FORENSIC SCI }\end{array}$ & 0.308 & 0.00016 & - & 36 & 4.44444E-06 & 0.4533334 \\
\hline RECHTSMEDIZIN & 0.814 & 0.00034 & - & 164 & 2.07317E-06 & 0.2114634 \\
\hline MED SCI LAW & 0.446 & 0.00048 & 0.109 & 241 & 1.9917E-06 & 0.2031535 \\
\hline ROM J LEG MED & 0.398 & 0.00015 & - & 169 & 8.87574E-07 & 0.0905325 \\
\hline
\end{tabular}

by Bergstrom, rates journals depending on the number of citations, weighted against the impact of the citing journals. ${ }^{[5]}$ The AIS is computed by dividing the EF score by the percentage of all articles present in the Journal Citation Reports published in a specific journal. Both are present in the Journal Citation Reports and are updated annually.

In order to get a more accurate assessment of the impact of researchers, this paper aims to propose a new method of quantification, based on the EF. Four calculation formulas are proposed which, taken together or separately, quantify the impact of researchers, and attempt to diminish the limits imposed by previous formulas.

\section{Method}

The basis for the calculations is a parameter called $\mathrm{E}_{\mathrm{mp}}$. In order to calculate the $\mathrm{E}_{\mathrm{mp}}$ we must identify the EF for the journal of interest, using the values from the Journal Citations Reports (JCR) tables. Then we divide the EF by the number of articles published in that journal, value taken from the JCR tables. This intermediary value is named $\mathrm{E}_{\mathrm{p} \text {. }}$ The next step is to identify the median value $\left(E_{m}\right)$ of the $E_{p}$ values in the ISI subject category of interest. $\mathrm{E}_{\mathrm{p}}$ equals $\mathrm{E}_{\mathrm{m}}$ for the journal located in the middle of the journal list (or equals the arithmetic mean of the two journals located in the middle, if the number of journals in the list is even). If a journal is present in more than one ISI category, we considered the smallest $\mathrm{E}_{\mathrm{m}}$ value for our analysis. The next step is to compute the $\mathrm{E}_{\mathrm{p}}$ to $\mathrm{E}_{\mathrm{m}}$ ratio For journals located in the middle of the journal list, the $\mathrm{E}_{\mathrm{mp}}$ value was 1 . An $\mathrm{E}_{\mathrm{mp}}$ higher than 1 is associated with journals with a higher than average impact in that scientific area, and a value below 1 is associated with journals having a lower than average impact in that scientific area. If a journal is present in more than one ISI subject category, the maximum value obtained was taken into account (division by the smallest $\mathrm{E}_{\mathrm{m}}$ ). Table 1 and 2 present two calculation examples for the following ISI categories: Medicine, Legal, and Anatomy \& Morphology.

\section{Calculations}

We used the $\mathrm{E}_{\mathrm{mp}}$ to obtain three scores. The article median score $\left(\mathrm{AE}_{\mathrm{mp}}\right)$ is calculated by summing the $\mathrm{E}_{\mathrm{mp}} \mathrm{s}$ for all articles published by a researcher. $\mathrm{AE}_{\mathrm{mp}}=\sum \mathrm{E}_{\mathrm{mp}}$. By only selecting the articles in which the researcher is a main author (first author, correspondent author, other relevant positions in various fields, like the last author in biomedicine), this parameter can quantify the article median score for the articles in which that researcher is a main author $\left(\mathrm{AE}_{\mathrm{mp}} \mathrm{Main}\right)$. The Article weighted median score $\left(\mathrm{BE}_{\mathrm{mp}}\right)$, 
Table 2: $\mathrm{E}_{\mathrm{mp}}$ in the the ISI Category of Anatomy\&Morphology

\begin{tabular}{|c|c|c|c|c|c|c|}
\hline Journal & IF & EF & AIS & NoArt & Ep & $E_{m p}$ \\
\hline $\begin{array}{c}\text { ADV ANAT } \\
\text { EMBRYOL CEL }\end{array}$ & 4 & 0.00059 & 1.239 & 3 & 0.000196667 & 4.9025839 \\
\hline DEV DYNAM & 2.536 & 0.03813 & 1.29 & 233 & 0.000163648 & 4.0794834 \\
\hline $\begin{array}{c}\text { BRAIN STRUCT } \\
\text { FUNCT }\end{array}$ & 5.628 & 0.00575 & 2.395 & 42 & 0.000136905 & 3.4128157 \\
\hline J ANAT & 2.37 & 0.01109 & 0.906 & 119 & 9.31933E-05 & 2.3231586 \\
\hline TISSUE CELL & 1.038 & 0.00133 & 0.308 & 16 & 0.000083125 & 2.0721726 \\
\hline J MORPHOL & 1.539 & 0.00557 & 0.608 & 110 & $5.06364 \mathrm{E}-05$ & 1.2622831 \\
\hline $\begin{array}{c}\text { CELLS TISSUES } \\
\text { ORGANS }\end{array}$ & 2.203 & 0.00483 & 0.731 & 97 & 4.97938E-05 & 1.2412797 \\
\hline $\begin{array}{l}\text { ACTA ZOOL- } \\
\text { STOCKHOLM }\end{array}$ & 1.133 & 0.00182 & 0.488 & 40 & 0.0000455 & 1.1342418 \\
\hline $\begin{array}{l}\text { MICROSC RES } \\
\text { TECHNIQ }\end{array}$ & 1.792 & 0.00662 & 0.612 & 150 & 4.41333E-05 & 1.1001730 \\
\hline ANAT REC & 1.473 & 0.00917 & 0.6 & 209 & 4.38756E-05 & 1.0937481 \\
\hline ZOOMORPHOLOGY & 1.283 & 0.00095 & 0.488 & 23 & 4.13043E-05 & 1.0296510 \\
\hline $\begin{array}{c}\text { APPL } \\
\text { IMMUNOHISTO M M }\end{array}$ & 1.63 & 0.00349 & 0.462 & 87 & 4.01149E-05 & 1 \\
\hline $\begin{array}{c}\text { FRONT } \\
\text { NEUROANAT }\end{array}$ & 3.068 & 0.00185 & - & 57 & 3.24561E-05 & 0.8090794 \\
\hline CLIN ANAT & 1.289 & 0.00399 & 0.333 & 134 & 2.97761E-05 & 0.7422708 \\
\hline ANN ANAT & 1.861 & 0.00201 & 0.349 & 68 & $2.95588 \mathrm{E}-05$ & 0.7368539 \\
\hline SURG RADIOL ANAT & 1.056 & 0.00346 & 0.333 & 135 & $2.56296 \mathrm{E}-05$ & 0.63890548 \\
\hline ANAT SCI INT & 0.833 & 0.00079 & 0.233 & 31 & $2.54839 \mathrm{E}-05$ & 0.6352719 \\
\hline $\begin{array}{l}\text { ANAT HISTOL } \\
\text { EMBRYOL }\end{array}$ & 0.899 & 0.00119 & 0.175 & 62 & 1.91935E-05 & 0.4784643 \\
\hline FOLIA MORPHOL & 0.521 & 0.00066 & - & 52 & 1.26923E-05 & 0.3163988 \\
\hline INT J MORPHOL & 0.244 & 0.00066 & - & 179 & 3.68715E-06 & 0.0919147 \\
\hline J ANAT SOC INDIA & 0.056 & 0.00008 & - & - & 0 & 0 \\
\hline
\end{tabular}

is calculated by summing the $\mathrm{E}_{\mathrm{mp}}$ values of the journals in which the author has published, divided by the number of authors: $\mathrm{BE}_{\mathrm{mp}}=\sum\left(\mathrm{E}_{\mathrm{mp}} / \mathrm{n}_{\mathrm{i}}\right)$. The Citation weighted median score $\left(\mathrm{CE}_{\mathrm{mp}}\right)$ is calculated by summing the $\mathrm{E}_{\mathrm{mp}}$ values of the journals in which the articles of the researcher were cited: $\mathrm{CE}_{\mathrm{mp}}=\sum \mathrm{E}_{\mathrm{mp}}$.

\section{Statistical analysis}

We used Microsoft Excel 2011 for Mac and SPSS v20 for calculating the parameters. The correlation between EF, Impact factor and $\mathrm{E}_{\mathrm{mp}}$ were computed using the Pearson correlation coefficient. A p value below .05 was considered statistically significant.

\section{RESULTS}

In order to show the usefulness of the above-mentioned parameters we will present a hypothetical situation. Suppose we have two authors, A and B, for which we would like compute the parameters. Both published five articles in the ISI category Medicine, Legal.

Author A has four papers published in the J LAW MED ETHICS, and one in the MED SCI LAW, having thus an $\mathrm{AE}_{\mathrm{mp}}=4 * 1.36+0.2=5.64$. Author $\mathrm{B}$ has one article published in the J LAW MED ETHICS, and four in MED SCI LAW, thus having an $\mathrm{AE}_{\mathrm{mp}}=4 * 0.2+1.36=2.16$. Even if both authors have the same number of article, the ones published by author $A$ had a higher $\mathrm{AE}_{\mathrm{mp}}$ value, suggesting they were published in higher impact journals, a fact that the simple count of ISI published articles was not able to identify.

Suppose now that both authors only published two articles. Author A wrote an article for LAW MED ETHICS along with six other authors, and an article for MED SCI LAW along with three other authors. The $\mathrm{BE}_{\mathrm{mp}}$ for this author would be $\mathrm{BE}_{\mathrm{mp}}=1.36 / 7+0.2 / 3=0.26$. Author $\mathrm{B}$ wrote 
Table 3: Correlations between $\mathrm{IF}_{\mathrm{f}} \mathrm{EF}$, and $\mathrm{E}_{\mathrm{mp}}$

\begin{tabular}{|c|c|c|c|c|}
\hline \multicolumn{2}{|c|}{ Legal Medicine } & \multirow{2}{*}{$\begin{array}{c}\text { IF } \\
1\end{array}$} & \multirow{2}{*}{$\begin{array}{l}\text { EF } \\
.473\end{array}$} & \multirow{2}{*}{$\frac{\mathrm{E}_{\mathrm{mp}}}{.737^{\text {** }}}$} \\
\hline & Pearson Correlation & & & \\
\hline \multirow[t]{3}{*}{ IF } & Sig. (2-tailed) & - & .075 & .002 \\
\hline & N & 15 & 15 & 15 \\
\hline & Pearson Correlation & .473 & 1 & .505 \\
\hline \multirow[t]{3}{*}{$\mathrm{EF}$} & Sig. (2-tailed) & .075 & - & .055 \\
\hline & N & 15 & 15 & 15 \\
\hline & Pearson Correlation & $.737^{* *}$ & .505 & 1 \\
\hline \multirow[t]{2}{*}{$E_{m p}$} & Sig. (2-tailed) & .002 & .055 & - \\
\hline & N & 15 & 15 & 15 \\
\hline \multirow[t]{2}{*}{$\begin{array}{l}\text { Anatomy \& } \\
\text { Morphology }\end{array}$} & IF & EF & $\mathrm{E}_{\mathrm{mp}}$ & - \\
\hline & Pearson Correlation & 1 & .250 & $.763^{\star *}$ \\
\hline \multirow[t]{3}{*}{ IF } & Sig. (2-tailed) & & .275 & .000 \\
\hline & $\mathrm{N}$ & 21 & 21 & 21 \\
\hline & Pearson Correlation & .250 & 1 & $.515^{*}$ \\
\hline \multirow[t]{3}{*}{$\mathrm{EF}$} & Sig. (2-tailed) & .275 & - & .017 \\
\hline & $\mathrm{N}$ & 21 & 21 & 21 \\
\hline & Pearson Correlation & $.763^{* *}$ & $.515^{*}$ & 1 \\
\hline \multirow[t]{2}{*}{$E_{m p}$} & Sig. (2-tailed) & .000 & .017 & - \\
\hline & $\mathrm{N}$ & 21 & 21 & 21 \\
\hline
\end{tabular}

**.Correlation is significant at the 0.01 level (2-tailed). *.Correlation is significant at the 0.05 level (2-tailed).

two articles for MED SCI LAW, both as a sole author. In this case, the author would have a $\mathrm{BE}_{\mathrm{mp}}=0.4$. Therefore, even if both authors have published the same number of articles, the overall contribution of author B was greater, even if the $\mathrm{E}_{\mathrm{mp}}$ of the journal in which he has published was smaller, because B was the sole author of those publications.

Suppose now that author $\mathrm{A}$ has an article cited five times, four of which in the J LAW MED ETHICS, and one in the MED SCI LAW; in this case $\mathrm{CE}_{\mathrm{mp}}=4 * 1.36+0.2=$ 5.64. Author $\mathrm{B}$ has a single article cited five times, once in J LAW MED ETHICS, and four times in MED SCI LAW. In his case $\mathrm{CE}_{\mathrm{mp}}=4 * 0.2+1.36=2.16$. As a result, although both have the same number of citations, the author $A$ was cited in journals with a far greater IF than author B (had increased visibility).

From Table 3 is obvious that $\mathrm{E}_{\mathrm{mp}}$ is strongly correlated with the IF of the journal, while its correlation with the EF score is much weaker (if present); the most likely explanation is represented by the fact that both IF and $\mathrm{E}_{\mathrm{mp}}$ are directly divided by the number of published articles.

\section{DISCUSSIONS}

The EF is calculated by analyzing the number of times an article is cited in journals published in the past five years, within the JCR of that year, while also taking into consideration the journals citing it. This means that the citation of articles in a journal with a higher impact factor has a bigger contribution on the overall score compared to the citations of articles published in a lower impact journal. Furthermore, self-citations do not influence the $\mathrm{EF},{ }^{[11]}$ therefore minimizing the weight of self-citations in the computed scores. Eigenfactor is derived from eigenvector centrality measures, a class of network statistics similar to the one used by Google to rank web pages. ${ }^{[12]}$ Briefly, the algorithm assigns quality scores to journals creating a citation network in which they are initially randomly selected. The citation list from this initial set is used by the network to select the next set of journals and this process continues indefinitely until it creates an hierarchical ranking of journals based on the frequency of citations. ${ }^{[13]}$ The EF Score is a measure of the total importance of a specific journal in the scientific community, implying that if a journal doubles the quality of articles whilst the quality of all journals' articles remains the same, the EF 
score of that journal doubles. ${ }^{[14]}$ The SCImago Journal Rank Indicator (SJR), also a variation of the Google PageRank algorithm, is similar to the EF; it is computed by weighting the sum of four parameters: minimum prestige (the same for all journals, but dependent upon the total database), the number of published articles on a three year period, the prestige of the citing journals and a rest term adding the contribution of the journals not connected to the citation network of the published articles. ${ }^{[6]}$ For a detailed analysis of the advantages of EF Score see Franceschet. ${ }^{[7]}$ We preferred to use the EF Score tables from Journal Citation Reports due to the availability of other scientometric indicators in these tables. Also, JCR is still considered as a de facto standard in evaluating the scientific production, ${ }^{[17,18]}$ even if recent literature revealed many limitations of this database, among which high cost, limited availability, a significant underestimation of the individual's actual citation impact (especially due to the removal of citations from $\mathrm{PhD}$ theses, books, and non ISI-ranked journals), poor aggregation of minor variations of the same title, limited coverage of non-English sources, incorrect appreciation of apostrophes and diacritics. ${ }^{[19]}$ In order to obtain $\mathrm{E}_{\mathrm{mp}}$ we divided the value obtained to the number of articles published in the respective journal for the number of years considered for the EF. The inclusion of this step led to a value relatively similar to that of the Article Influence Score in regard of the relative position of a journal in a specific ISI subject category. We preferred not to use the AIS and replaced it with the EF/number of articles because the AIS is not automatically calculated in the JCR for all journals; therefore its use would have lead to the exclusion of recently indexed journals from our calculation.

The division of the EF value of the journal of interest by the median value of the EF for that ISI subject category allowed us to easily compare the impact of different journals in various fields. Thus, a researcher publishing in a journal positioned in the middle of the list in the field of Genetics would have an $\mathrm{E}_{\mathrm{mp}}$ of 1 , similar to a researcher in the field of medical informatics, even if the impact factor or the EF score for the two journals would be markedly different. A similar calculation, but based on the AIS was used for university promotion in Romania ${ }^{[21]}$ The method required the computation of an influence score. The calculation started with the identification of the median influence score for an ISI category, which was equal to the median of AISs of the journals in the field at hand, having non-zero values. The influence score of a scientific journal was then computed as the ratio between the influence score of that journal and the reference influence score corresponding to the area in which that journal was included.
$\mathrm{AE}_{\mathrm{mp}}$ can be considered as a score replacing the impact factor, as it is based upon the number of articles written by a certain researcher, weighted against the value of the journals in which they are published. Articles published in higher rating journal are usually a result of more important works, exposed to a more difficult peer-review process and usually have a wider audience. The $\mathrm{AE}_{\mathrm{mp}}$ score underlines these issues by assigning a higher value to articles published in a higher impact journals. $\mathrm{AE}_{\mathrm{mp}}$ allows for the easy comparison between the scientific production of authors in different fields, regardless of the citation pattern in those specific scientific areas.

Another potential use of $\mathrm{AE}_{\mathrm{mp}}$ is represented by the identification of the importance of journals in which a certain author publishes. For the same purpose Bornmann et al, by using complex mathematical computations, developed three scores $-h^{2}$ upper, $h^{2}$ center, $h^{2}$ lower. The first one includes articles cited more than the value of the $h$ index, the second - articles cited around the value of the $h$ index, and the third, articles cited less than the value of the $h$ index. Authors with a higher first index are considered as perfectionists and authors with the highest third index are considered as mass producers of scientific material. The total amount of the three indexes is 100 and the values are provided as percentages ${ }^{[10]} \mathrm{By}$ dividing $\mathrm{AE}_{\mathrm{mp}}$ to the number of articles published by a certain researcher, is it possible to identify the publishing pattern of a specific researcher - a value exceeding 1 means that he/she mainly publishes in higher than average journals, while a value below 1 means that she/he mainly publishes in lower than average journals. $\mathrm{AE}_{\mathrm{mp}}$ can be used instead of the $\mathrm{h}$ upper, center, and lower method developed by Bornmann, having as main advantages the removal of self-citations from the calculus and the ease of use.CE $\mathrm{Cm}_{\mathrm{mp}}$ is calculated as the sum of $\mathrm{E}_{\mathrm{mp}} \mathrm{s}$ for all citations in published articles by a researcher. This score may be used as a replacement for h-index, having as a main advantage the fact that it doesn't depend on the field of work. A major disadvantage of h-index is its dependence on the period in which a certain researcher published, which is not the case with $\mathrm{CE}_{\mathrm{mp}}$ that may increase significantly even with a relatively small number, but highly cited articles. Another disadvantage of the h-index, which also occurs when using the $\mathrm{CE}_{\mathrm{mp}}$, is that it does not take into account the number of authors participating in a publication. In order to correct this fact, we proposed a third score, $\mathrm{BE}_{\mathrm{mp}}$, which weights the scores obtained by the $\mathrm{E}_{\mathrm{mp}}$ with the number of authors. The use of this score in university promotion or accessing grants would have a great advantage by limiting the addition of authors to articles without them actively participating in the study, because every 
addition would decrease the $\mathrm{BE}_{\mathrm{mp}}$ score of all other authors. Another disadvantage for all scores previously presented is that they do not quantify the relative importance of authors of a study. For example, the first author theoretically has a bigger contribution the other authors. The relative contribution of each author is highlighted in several research fields by the manner in which the author list is arranged, with the first author having the greatest role in elaborating the article. In working fields where this is used as a current practice, an $\mathrm{AE}_{\mathrm{mp}}$ equivalent score ( $\mathrm{AE}_{\mathrm{mp}}$ Main) may be used by taking into consideration only the articles in which an author is a main author, such as first author or correspondent author.

In conclusion the concomitant use of the three parameters would allow for an alternate method of quantification of a researcher's scientific value. By using the $A_{m p}$ score we will be able to properly quantify the number of published articles weighted with the prestige of the publishing journals, which would allow us to easily compare authors in different fields. Our methods also allow us to evaluate the scientific impact of works published as a main author, by computing the $\mathrm{AE}_{\mathrm{mp}}$ Mainscore. By using the $\mathrm{BE}_{\mathrm{mp}}$ we can limit the addition of authors not meeting authorship criteria according to the ICMJE. ${ }^{[21]}$ By using conjointly $\mathrm{AE}_{\mathrm{mp}}$ Main and $\mathrm{BE}_{\mathrm{mp}}$ we can identify, within a collective, the relative contribution of each researcher to a specific scientific outcome. The number of citations weighted with the prestige of the journals citing them $\left(\mathrm{CE}_{\mathrm{mp}}\right)$ would allow the visualization of the manner in which other researchers evaluate the scientific value of a specific researcher/group/institution, as well as the visibility of conducted research.

The main limitation of these parameters is a somewhat difficult calculation methodology. Nevertheless, with the availability of JCR databases, it is possible to compute the $\mathrm{E}_{\mathrm{mp}}$ values easily, and the calculation of the coefficients for each researcher can be manually or automatically generated through Excel/php scripts.

\section{REFERENCES}

1. Hostiuc S, and Curca CG. 2012. Etica publicarii stiintifice. Cluj Napoca: Casa Cartii.

2. Hirsch JE. 2005a. An index to quantify an individual's scientific research output. Proceedings of the National Academy of Sciences of the United States of America 102:16569-16572. 10.1073/pnas.0507655102
3. Glänzel W. On the h-index-a mathematical approach to a new measure of publication activity and citation impact. Scientometrics. 2006; 67(2):315-21.

4. Waltman L, and van Eck NJ. The inconsistency of the h-index. Journal of the American Society for Information Science and Technology. 2012;63(2):406-15.

5. Bergstrom C. Measuring the value and prestige of scholarly journals. College \& Research Libraries News. 2007;68(5):314-6.

6. Hirsch JE. An index to quantify an individual's scientific research output. Proceedings of the National Academy of Sciences of the United states of America. 2005;102(46):16569-72.

7. Schreiber M. A modification of the h-index: The hm-index accounts for multi-authored manuscripts. Journal of Informetrics. 2008;2(3):211-6. 10.1016/j.joi.2008.05.001

8. Egghe L.Theory and practise of the $\mathrm{g}$-index. Scientometrics. 2006;69:131-52. 10.1007/s11192-006-0144-7

9. Zhang C-T. 2009. The e-Index, Complementing the h-Index for Excess Citations. PLoS ONE 4:e5429. 10.1371/journal. pone. 0005429

10. Bornmann L, Mutz R, and Daniel H-D. 2010. The $h$ index research output measurement: Two approaches to enhance its accuracy. Journal of Informetrics. 2010;4(3):407-414. 10.1016/j. joi.2010.03.005.

11. Kozak M, and Bornmann, L. 2012. A New Family of Cumulative Indexes for Measuring Scientific Performance. PloS one. 7, e47679.

12. Miller CS. Impact versus impact factor and Eigenfactor. Oral Surgery, Oral Medicine, Oral Pathology and Oral Radiology. 2012;113(2):145-6. 10.1016/j.tripleo.2011.08.009

13. Bergstrom CE. b. Measuring the value and prestige of scholarly journals. Coll Res Libr News. 2007;68(5):314-6.

14. Rizkallah J, and Sin DD. Integrative approach to quality assessment of medical journals using impact factor, eigenfactor, and article influence scores. PLoS ONE 5:e10204.

15. Bergstrom CT, West JD, and Wiseman MA. The Eigenfactor ${ }^{\mathrm{TM}}$ metrics. The Journal of Neuroscience. 2008;11433-4.

16. Gonzales-Pereira B, Guerrero-Bote VP, and Moya-Anegon F. The SJR indicator: a new indicator of journals' scientific prestige. 2011. arXiv preprint arXiv:0912.4141.

17. Franceschet $M$. Ten good reasons to use the Eigenfactor ${ }^{\mathrm{TM}}$ metrics. Information Processing \& Management. 2010. 46:5558, doi:http://dx.doi.org/10.1016/j.ipm.2010.01.001.

18. Garfield E. The history and meaning of the journal impact factor. JAMA: The Journal of the American Medical Association. 2006;295(1):90-3.

19. Smith LC. Citation analysis. Library trends. 1981;30I(1):83-106.

20. Harzing A-W and Van der Wal R. Google Scholar: the democratization of citation analysis. Ethics in Science and Environmental Politics. 2007;8(1):61-73.

21. Romanian Ministry of Education. 2011. Ordin privind aprobarea standardelor minimale necesare și obigatorii pentru conferirea titlurilor didactice din învățămâtul superior, a gradelor profesionale de cercetare-dezvoltare și a atestatului de abilitare, pentru domeniile științifice aferente panelurilor pe domenii fundamentale P1-Matematică și științe ale naturii, P2-Științe inginerești și P3-Științe biomedicale din cadrul Consiliului Național pentru Atestarea Titlurilor, Diplomelor și Certificatelor Universitare. In: MINISTERUL EDUCAȚIEI, TINERETULUI ŞI SPORTULUI, editor. Order No. 4478/2011.

22. ICMJE. 2012. Uniform Requirements for Manuscripts Submitted to Biomedical Journals. Updated April 2010. Available at http:// icmje.org/urm_main.html(accessed 11.11.2012. 